\title{
Representations of Hungary and Transylvania in John Paget's Travelogue ${ }^{1}$
}

\author{
Borbála BÖKÖS \\ Partium Christian University (Oradea, Romania) \\ Department of English Language and Literature \\ bokosborbala@gmail.com
}

\begin{abstract}
Hungary was an important destination for British travelers in the nineteenth century, whose travel accounts provide intriguing insights into the cultural and political climate of the period. John Paget's journey was meticulously recorded in his extensive book entitled Hungary and Transylvania (1839) that served as a travel guide for other British visitors after him. Paget, who took part in the 1848/49 War of Independence, and became a "Hungarian," opened Europe's eyes to the Hungarian people and their country, destroying several false myths that existed about Hungarians in Western Europe, thus attempting to shape up a more favorable picture about them. The present paper examines a few questions regarding the representation of Hungary and of Transylvania in general in the travelogue: how did Paget describe particular cities and regions, the inhabitants, as well as their everyday life? I will attempt to look at the (changing) images of Hungary and Transylvania in Paget's writing, as well as to offer an insight into Hungarian society and culture in the nineteenth century as contrasted to English culture and politics.
\end{abstract}

Keywords: nineteenth century Hungary and Transylvania, travel literature, cultural representation.

\section{Introduction}

In the nineteenth century British travelers found new, exciting destinations: Hungary and Transylvania. The travelogues of English visitors provide intriguing insights into the cultural and political climate of the era. Among the many factors that made Hungary a desirable destination for foreigners one can enumerate the improvement of travelling conditions due to the appearance of steam-shipping, the Hungarian elite's receptive attitude towards British political and cultural models, as well as the newly occurred business opportunities (investing into railway, bridge building, and so on).

1 This research was funded by Sapientia Foundation - Institute of Research Programmes. 
Hungarian social transformation emerged as a result of increasingly influential West European liberal ideas spreading during the Age of Reform. According to László Kósa, as Count István Széchenyi took up a significant political role and became the central figure of the reform movement, the program of social transformation focused on the concept of the unification of interests (gentry and big landlords, Hungarians and non-Hungarians, as well as various religious denominations), unique in the process of European transformation. Moreover, the bourgeois liberal changes of the state were closely linked to the realization of national self-determination (1999, 164-165). Vienna considered such reform trends as being major threats to imperial centralization. Thus, political struggles became more and more ardent. ${ }^{2}$

Among such circumstances the ways in which Hungarians and their cause were seen by Western Europeans seemed to be of utmost importance. As the causes of nation and progress were closely linked, it became crucial for Hungarians to be seen positively by foreigners - a demand that was going against the Habsburgs' interests. Among the many visitors that tried to depict a quite unbiased picture of Hungary one can find John Paget, whose journey was meticulously recorded in his extensive book entitled Hungary and Transylvania (1839). This work served as a travel guide for other British travelers. Paget also became famous for becoming a "Hungarian." His travelogue provided a positive image of Hungarians as well as of the Hungarian War of Independence, ${ }^{3}$ and served as a crucial source of information for the Western society regarding the situation in Hungary before the War of Independence in 1848. Thus, in my view, Paget's travelogue can be seen as a proto-imagological charting of Hungarians, in which the outsider's perception and representation of "national character" combine both a historical and an anthropological point of view on the issue of nationalism. As Joep Leerssen argues, the "informal, anecdotal belief in different national characters (...) became embedded in the comparative-historical paradigm that dominated the human sciences" in the nineteenth century (Beller-Leerssen, 2007, 17), and, thus, in the pre-history of imagology "the various stereotypes and assumptions concerning national peculiarities never form the topic of investigation, but always part of the interpretative tool-kit; they are explanations rather than explicanda" (BellerLeerssen, 2007, 19). While talking about imagology's working on literary texts, Leerssen asserts that the issue of subjectivity must be taken into account, and

2 Henry Marczali argues that "the history of Hungary is a record of an almost unbroken struggle between the older Magyardom and foreign - particularly German - influences" (1910, 230). He adds that "individual members of the aristocracy abandoned the ancestral customs and even the language, but the nobility, as a body, remained Hungarian in feeling and threw its whole political weight into the defense of Hungarian nationality" $(1910,231)$.

3 The War of Independence was one of the many European revolutions of 1848, the "spring of nations," attempting to undermine the Habsburgs' system of alliance of European powers, and subsequently overthrow Metternich’s conservative power in Austria (Kósa 1999, 169). 
that the "nationality represented (the spected) is silhouetted in the perspectival context of the representing text or discourse (the spectant)" (Beller-Leerssen, $2007,27)$. What emerges in the case of Paget's book is a dynamic interplay between the images that characterize the Other and the self-image of the traveler, ${ }^{4}$ an interplay that leads to a unique, both subjective and objective reflection on Hungary and Transylvania.

The present paper examines a few questions regarding the representation of Hungary and of Transylvania in general in the travelogue: how did Paget describe particular cities and regions, the inhabitants, as well as their everyday life? I will attempt to look at the (changing) images of Hungary and Transylvania in Paget's writing, as well as to offer an insight into nineteenth-century Hungarian society and culture as contrasted to English culture and politics. The essay interprets and analyzes Paget's travelogue by looking at its special role and standing in AngloHungarian studies, as well as in the field of travel literature about Hungary. Since there are very few studies available on the life and work of John Paget, this essay also attempts to fill this gap in the critical body of Paget's oeuvre. On the one hand, such an analysis would contribute to our general understanding of an era and a country that were seen by a foreigner who ultimately became a "Hungarian." On the other hand, the discussion of Paget's work will hopefully provide an understanding of nineteenth century Hungary's culture and society, as well as its place in Europe; that is, an interpretation of the past that is undoubtedly an integral part, and in the service of constructing a present history.

\section{John Paget: a Short Biography}

John Paget was born in Loughborough on the $18^{\text {th }}$ of April 1808, as the son of Joseph Paget and Anne Paget. The wealthy family moved to Thrope Satchville in 1821; that is why later many considered John Paget as the native of this town.

Young John Paget together with his brother, Arthur, began his education at the Unitarian Manchester College in York, and, following the family traditions, studied medicine there. In 1827 he further pursued his studies of medicine at Trinity College in Dublin, and, in 1831, obtained his M.D. diploma in Edinburgh. Although his dissertation on heart diseases was highly appreciated among scholars in the field, and later he obtained prizes in medical science, he never used his M.D. title, and never practiced as a doctor.

After the death of his father in 1833 he left the country and dedicated himself to traveling and studying in the various cities of Europe. He spent a brief period of time in Paris, then he visited Frankfurt, Heidelberg, Salzburg, Munich, and so

4 Beller Manfred argues that the image "is the mental silhouette of the other" (Beller-Leerssen 2007, 4). 
on. In 1835 he went to Rome, where he met Baroness Polyxenia Wesselényi, an elegant, enlightened Hungarian aristocratic woman, whom he married in 1837. ${ }^{5}$ After travelling in Hungary and in Transylvania he settled down in Transylvania, and became a highly appreciated member of the landed gentry. On his adopted land he became a devoted "Hungarian:" he learned the language, befriended István Széchenyi and Miklós Wesselényi, fought in the Hungarian War of Independence, and supported the Unitarian Church and Unitarian education in Transylvania. He also gained reputation as an agriculturist, since he introduced in Transylvania a special treatment of viniculture, as well as an improved breed of cattle. He (re)introduced horse-breeding, horseracing, and fox-hunting in Transylvania. His estate in Câmpia Turzii (Aranyosgyéres) became the model for, and played an important role in, the development of modern viniculture in nineteenth century Hungary. The Paget family's estates both in Câmpia Turzii and in Cluj-Napoca became important cultural centres; English and American travelers, as well as members of the Hungarian and Transylvanian upper-class were always welcome.

To develop Transylvanian cultural life and to strengthen English and Hungarian relations, Paget attempted to popularize English language: in 1878 he founded the Conversation Club, an Anglo-Hungarian social circle, in which members could also use the great Paget library (more than two thousand English books and the two important English papers: Athenaeum and the Pall-Mall Gazette to which Paget was a regular subscriber).

John Paget and Polyxenia Wesselényi had twin sons: Arthur and Oliver (born on the $5^{\text {th }}$ of September 1841). Unfortunately both boys died young: Arthur died when he was only twelve years old, and Oliver, himself a soldier serving under Garibaldi, passed away when he was twenty-two.

John Paget died on the $10^{\text {th }}$ of April 1892, and was buried in Cluj-Napoca.

\section{On John Paget's Travelogue}

Paget's interest in Hungary and Transylvania was raised first when he met Polyxenia in 1835. In the spring of 1835 he travelled to Hungary together with his friends: William Stanford (1806-1882), an English journalist, and George Edward Hering (1805-1879), an English landscape painter. His experiences were

5 The friendship that developed into love is described from Polyxenia's point of view as well: she kept a diary entitled Olaszhoni és schweizi utazás [Travels in Italy and Switzerland] that was published in 1842 in Cluj-Napoca (Kolozsvár) edited by János Győri. A recent edition of the diary was published in 2006, edited by Klára Lingvay (Kriterion Publishing House, Cluj). Her writing also offers a unique perspective on the condition of women in the nineteenth century and speaks ironically about the shortcoming of the upper-class as well as the institution of marriage, thus providing a compelling social criticism of the era. 
recorded in his Hungary and Transylvania; with Remarks on their Condition Social, Political, and Economical that was published in London in 1839. The book became highly successful in London, and Hering's illustrations that accompanied it were also published in a companion volume in 1838 entitled: Sketches on the Danube, in Hungary, and Transylvania.

Paget's travelogue was very successful in London during the Hungarian War of Independence in 1849, and in the following years it was republished four times. It was first published in the United States of America in 1850, shortly before the arrival of Lajos Kossuth (Maller 1985, 339). Maller adds that Paget's work was the most truthful account of Hungary and its inhabitants in those years, and, because of it, Paget was elected member of the Hungarian Historical Society (Magyar Történelmi Társaság) in 1868 (1985, 339). The first Hungarian translation appeared in 1987, and, according to the editor of this translated volume, Sándor Maller (1985), Paget's work was the most beautiful and well documented work on Hungary and Transylvania written in English in the nineteenth century. The latest edition of the book appeared in 2011 in Cluj (Kolozsvár) and is, indeed, a very thorough work that completes the selective translation of Maller, while adding the translation of Paget's Memoires VI, a diary in six notebooks written in June, July, and August 1849 dealing with the Hungarian War of Independence. The diary, now preserved in the Széchenyi Library, is a precise description of daily events both in terms of military movements and local, family life. As Klára Cs. Lingvay, the editor and translator of the volume argues, Paget provides a shattering picture of the historical atmosphere that pervaded Cluj before the occurrence of the great national tragedy: the crush of the War of Independence (2011, 35).

John Paget's Hungary and Transylvania is quite an unusual travelogue: besides providing the traveler's personal experiences, it offers a thorough social, political, religious as well as economic description of the country. This more than ninehundred-page account of Hungary in the Reform period, together with its positive and negative aspects, shaped the new ways in which Hungarians were perceived by Western Europeans. Paget even considered one of his great missions to provide a favorable picture of Hungary for Westerners, as he wrote in the introduction of his travelogue: "I would not willingly deceive him [the reader] in anything. I am deeply interested in the welfare of Hungary, and I have thought that one great means of promoting it would be to extend the knowledge of that country in the west of Europe, and more especially in England" (1839, vii).

In the second chapter of his work Paget even mentioned an anecdote about how Hungarians complained about Englishmen's lack of interest in Hungary.

In truth, our ignorance of Hungary is bitterly complained of by the Hungarians: "You are more interested in England about the cause of the South Sea Islands than about us Protestant constitutional Hungarians; you know more of the 
negroes in the interior of Africa than you do of a nation in the east of Europe." "This is undoubtedly true, but how can we help it?" was my answer. "Neither your newspapers nor those of Germany dare give us any information on your politics; for if they do, they know that their Austrian circulation is lost, as they are stopped at the frontiers, and besides the difficulties of travelling in the country, it is by no means easy to procure a passport at Vienna for that purpose." We both regretted that between two nations who had each so much that the other required, such mutual ignorance should prevail, and we could only hope that steam-navigation would break down the barrier which had hitherto been found insurmountable. (1839, 235-236)

In his work Paget provided a detailed description of Hungarian realities, emphasizing the positive aspect of specific Hungarian virtues and values (such as, desire for freedom, the beauty of music and language and their shaping force of national identity), as well as the sympathy of Hungarians towards English culture and language.

\section{Anglo-Hungarian Relations}

The great merit of Paget's travelogue is that it offers a realistic picture of nineteenth century Hungary and Transylvania. The English traveler described both the positive and the negative aspects of the country, while constantly comparing Hungarian institutions, cultural life, as well as the inhabitants to English standards. The chapter about Transylvania begins as follows:

A strange little country is this Transylvania! Very likely the reader never heard its name before, and yet some hundred years ago it was in close alliance with England; and, long before religious liberty, annual parliaments, payment of members, and the election of magistrates were dreamed of, amongst us, they were granted to Transylvania, by a solemn charter of their Prince, the Emperor of Austria. Here is this country on the very limits of European civilization, yet possessing institutions and rights, for which the most civilized have not been thought sufficiently advanced. $(1839,181)$

Throughout his journeys, he compared various Hungarian national specificities to English ones: he discussed the British Constitution and the Golden Bull of 1222, the love of liberty of both Hungarians and Englishmen, the Casinos in Hungary and the English Clubs, the mutual influences on literature and culture. While he praised the precious cultural and social achievements of the country, the new buildings, scientific societies, luxurious balls of the elite, he never forgot 
to mention the lack of progress and development in some areas, especially when it came to roads and ways of travelling. He often complained about the condition of the roads in Transylvania:

I believe my duty, as an honest chronicler of my travels, would be to give the reader at least two pages of tirade against the bad roads of Transylvania; for if I do not, how can I convey to him an impression of the misery we suffered while we were dragged over or rather through them? But lest he should grow as tired of hearing of them as we did of travelling on them, I will spare him the infliction, and content myself with saying that we now occupied three days in accomplishing what one day suffices for in summer. $(1839,212)$

But he appreciated the beauty of Transylvanian cities and the refinement of their inhabitants. About Cluj-Napoca (Kolozsvár / Klausenburg) he wrote:

[I]t is a pretty little town of about twenty-five thousand inhabitants, situated in the valley of the Szamos, and overlooked by hills on every side. It is built round a large square, in the centre of which stands the fine old Gothic cathedral. From this square, almost all the streets run off at right angles. The streets themselves are wide, in the true Magyar taste, and the houses, though handsome, are often of only one story, and never more than two. [...] Though, generally speaking, Klausenburg can lay no claim to figure as a European capital, yet it possesses some few houses which would make a respectable appearance in London or Paris. (1839, 397-399)

Moreover, because of the famous Transylvanian hospitality he immediately felt himself at home in the city. About social life he claimed that " $[\mathrm{t}] \mathrm{he}$ habits of society in Transylvania, in many respects, differ little from those of England about the end of the last century" $(1839,425)$, thus suggesting the superiority of the British civilization.

Later, while visiting Târgu Mureş (Marosvásárhely / Neumarkt), he expressed his disillusionment and dissatisfaction with the city, but he mentioned with admiration the "fine library of the Telekis" (1839, 316), the two Colleges, and the Casino that seemed a "flourishing and well-conducted establishment" (1839, 317). About Braşov (Brassó / Kronstadt) he said that it looked like a little Manchester (1839, 357), and he considered Oradea (Nagyvárad / Großwardein) “one of the prettiest little towns" that had its greatest glory "in its gilded steeples, its episcopal palace, its convents, and its churches" (1839, 440). While talking about Oradea's architecture he mentioned the Magyar, that is, Hungarian taste regarding the outlook of the squares and the buildings, and claimed that the Hungarian "loves not the narrow lanes and high houses of his German neighbours” (1839, 440). 
Paget made similar comparisons during his visits in Budapest, where he was impressed by the quick development of the city and Count István Széchenyi's ideas of reform. He noted that there was a certain - sometimes quite exaggerated - interest on the part of Hungarians in everything that was English. He called this "Anglomania," and not only referred to the flourishing cultural relations between English and Hungarian circles, but also to the great enthusiasm with which the Hungarian elite tried to imitate the British taste in almost every field of life. Paget provided a detailed description of the men's clothing pieces (the traditional Hungarian uniform), claiming that these were cherished as signifiers of the Magyars' nationalism: "I know of no dress so handsome, so manly, and at the same time so convenient. It is only on gala days that gay and embroidered dresses are used; on ordinary occasions, as sittings of the Diet, county meetings, and others" $(1839,420)$. He claimed that many of the traditionalists preferred this uniform, while "others follow the rest of the world in imitating England; nay, so much is Anglomania now the mode, that a fashionable tailor of Pest never dreams of pleasing his customers without assuring them he makes their coats according to the last pattern received from London" $(1839,421)$.

Indeed, Anglomania appeared as a cultural phenomenon in the nineteenth century Hungary due to the noble Hungarians' experiences abroad. As László Országh (1979) pointed out, many Hungarian aristocrats who came in touch with British values attempted to introduce Western elements in local customs, language, literature, architecture, as well as in various art forms. In fact, it was a kind of obligation for every respectable Hungarian young nobleman to spend some time abroad and study, if possible, in London. No wonder that English gardens appeared everywhere on noblemen's estates, and new, "British ways" were introduced in agriculture as well as in economy. More and more aristocrats started to build their houses in an English - Gothic - style (1979, 22-31).

Count István Széchenyi played an important role in the spreading of British influence among the Hungarian elite. He was the most ardent ambassador of British culture and industry in Hungary: from sports (riding) to establishing Club life he was engaged in all kinds of social reforming processes. English culture and literature gained ground among the Hungarian artists and the reading public. A great number of poets and novelists fell under the influence of the greatest English literary figures: Shakespeare, Byron, Scott, Milton. All these elements of "Anglomania" undoubtedly served as means of going against the German influence. As a result of Western influence, big cities, such as Budapest were impressively developed, but - as Paget correctly observed - the provinces still remained in a state of backwardness. 


\section{On the Images of People and Places}

In order to provide the best description of the Hungarians and the specific character of the "Magyar," Paget claimed that one had to visit Debrecen and the region of the "puszta," that is, the Great Hungarian Plain. This was the place where the language was spoken in its purest form and where people were strongly clinging to the preservation of their national identity. Language and religion were the two most important factors that determined the national identity of the Magyar (Paget 1839, 520). After observing the habits, the customs, and the manners of Hungarian people, he came to the following conclusions:

The Magyar character has a singular mixture of habitual passiveness and melancholy, mixed up with great susceptibility to excitement. The Magyar's step is slow and measured, his countenance pensive, and his address imposing and dignified. [...] It is wonderful how completely he has imparted his own character to his national music. Nothing can be more sad and plaintive than the commencement of many of the Hungarian airs. One of the most strongly characteristic of these is the Rákótzy, a march of the times of the revolutions of the Rákótzys, whose name it bears. As often happens with a revolutionary air, it has now become the national air of the country; and great is the honour of the gipsy fiddler who can play the Rákótzy with the true spirit. (1839, 504-505)

Paget was deeply touched by the hospitality of the Hungarians, and claimed that their habits were "but ill replaced by the cold egotistical formalities substituted for it in the intercourse of what is called, par excellence, the world" $(1839,521)$. As usual, he mentioned the greatest flaws in the Hungarian character: the personal pride that gave birth to jealousy against anyone who was able to succeed in the matters of the world. "[T]here are few countries in which a great man makes more personal enemies, and has to combat more petty annoyances, than in Hungary" (1839, 521). He characterized Hungarian language as follows:

"I cannot characterize the Hungarian as either soft or musical, but it is strong, energetic, manly; the intonation with which it is uttered, gives it in ordinary conversation a melancholy air, but when impassioned nothing can exceed it in boldness" (1839, 29).

While describing the portraits of everyday people he was stunned by the image of the "puszta" shepherds. With respect to their way of life, he emphasized their nomadic, "half-slothful, half-adventurous" lifestyle (1839, 496). He identified two specific elements that functioned as peculiarities of national identity in the case of the shepherds: the "Bunda," or hairy cloak $(1839,497)$ and the short pipe stuck in a shepherd's boot, and "in his belt a tobacco-bag, with a collection of 
instruments, - not less incomprehensible to the uninitiated than the attendants of a Scotch mull, - intended for striking fire, clearing the pipe, stopping the tobacco, pricking the ashes" $(1839,498)$. On another occasion, when visiting the land of the Szeklers in Transylvania, Paget also remarked the local people's resemblance to Scottish people:

The Szeklers inhabit a mountainous country, and are consequently poor; but it was easy to see they are far more industrious than any of the Transylvanians we had before visited. From all I heard of their character, they scorn a good deal to resemble the Scotch. The same pride and poverty, the same industry and enterprise, and if they are not belied, the same sharp regard to their own interests. $(1839,319)$

Among the national characteristics of Hungarians, Paget mentioned two outstanding features: the excessive use of tobacco and the moustache. He described smoking as a quintessential Hungarian habit which was practiced excessively in every part of the country. The Englishman's shock in regard to this unusual quantity of smoking was mentioned many times in the travelogue:

If I complained that the Casino of Pest was invaded by the pipe, what shall I say of that of Klausenburg? Its air is one dense cloud of smoke, and it is easy to detect any one who has been there by the smell of his clothes for some time after. Such a smoking nation as this I never saw; the Germans are novices to them in the art. Reading, writing, walking, or riding, idle or at work, they are never without the pipe. Even in swimming, I have seen a man puffing away quite composedly. (1839, 431-432)

Such an exaggerated consumption of tobacco was identified as an exclusively masculine habit and it was much disliked by the genteel Hungarian ladies. Moreover, it was also seen as a cultural code, a symbol of patriotic feelings and national values. As Alexander Maxwell claims, "tobacco smoking marked the patriot with other social variables. Hungarian smoking transcended ethnic differences, spreading beyond ethnic Hungarians to non-Magyar citizens of the Hungarian kingdom” $(2012,10)$.

Paget also wrote quite extensively about the moustache, this typical feature of every "Magyar." Once he visited a school for the deaf and the dumb, and to his great surprise the sign used by them for expressing the notion of "Hungarian" was "touching the upper lip indicating a moustache" $(1839,321)$. Later, when he met a Hungarian soldier, he was amazed by the length and the outlook of his moustache: 
[H]e presented himself to us with his smart uniform, rattling spurs, strong stick, and military swagger, set off by the most exaggerated pair of mustaches I had ever seen. [...] I do not think I exaggerate when I say his mustaches were more than a foot long from tip to tip, as the ornithologists express it; standing out on each side of his face as stiff, straight, and black as wax could make them. $(1839,463)$

Upon arriving to Hungary Paget observed that the country had a multi-ethnic composition, and wherever he travelled he offered a detailed description of the various ethnic groups as contrasted to the mainstream Hungarian population, as well as to English standards. According to Joan P. Rubies, ethnographic descriptions were considered to be central to travel narratives $(2002,244)$, since they were meant to inform those at home about the natives of a foreign land. During his tour in Transylvania Paget remarked about the Saxons, for example, that they are "slow people, suspicious of their neighbours, and caring more for material than political interests," but later he added that the Saxons are "undoubtedly the most industrious, steady, and frugal of all the inhabitants of Transylvania, and they are consequently the best lodged, best clothed, and best instructed" (1839, 354-355). About the gypsies he learned that they are "such rogues that they are scarcely permitted to enter any house" $(1839,160)$.

On the route towards Cluj-Napoca the travelling company met a sixteen-yearold gypsy girl, Lila, who became their guide and servant. Paget mentioned that the girl was very pretty, "with features more regular than those of her tribe commonly are, but with all a gipsy's cunning flattery on her tongue" $(1839,159)$. The sketch Herring made about the girl perfectly matches Paget's detailed ethnographic description: Lila had a fanciful, embroidered dress, a colored fillet over her forehead ornamented with a gay bow, and flowers in her brown, curly hair. "She spoke alternately Wallack, Magyar, and German, as she in turns scolded, directed, and coaxed" $(1839,160)$.

As a true British traveler, Paget recorded every detail of the customs and the lifestyles of the natives, and attempted to offer an unprejudiced picture of people. Yet, his viewpoint was often determined by his English background and social patterns, thus, many times, he looked at the "otherness" of Hungarians with confusion, especially when some aspects did not meet his aforementioned English standards. 


\section{Conclusions}

John Paget in his travelogue provided a new picture about Hungary and Transylvania for the English public. His book introduced the English people to life in a country that was previously considered to be an exotic, remote place, as well as a dangerous, hidden land. He described a nation that was both strongly preserving its national identity and embracing British ideas and the new waves of social as well as economic progress. By describing the cultured elite of the country, the real condition of peasants and nobles, the progressive spirit of Magyars, and by offering a compelling portrait of Count Széchenyi, Paget - going against the Habsburgs' interests - undoubtedly contributed to the debunking of false myths that were constructed about Hungarians in Western Societies.

\section{Works Cited}

Beller, Manfred and Joep Leerssen, eds. 2007. Imagology. The Cultural Construction and Literary Representation of National Characters. A Critical Survey. Amsterdam: Rodopi.

Cs. Lingvay, Klára. 2011. Paget, John. Magyarország és Erdély. Napló. [Hungary and Transylvania. A Journal.] Cluj-Napoca: Kriterion.

Hering, George Edward. 1838. Sketches on the Danube, in Hungary, and Transylvania. London: Thomas McLean.

Kósa, László, ed. 1999. A Companion to Hungarian Studies. Budapest: Akadémiai. Maller, Sándor. 1985. Paget, John. Magyarország és Erdély. Válogatás. [John Paget. Hungary and Transylvania. Selection.] Trans. Rakovszky Zsuzsa. Budapest: Helikon.

Marczali, Henry. 1910. Hungary in the Eighteenth Century. Cambridge: Cambridge UP.

Maxwell, Alexander. 2012. "Tobacco as Cultural Signifier: a Cultural History of Masculinity and Nationality in Habsburg Hungary." AHEA: E-journal of the American Hungarian Educators Association vol. 5: 1-19.

Országh, László. 1979. "Anglomania in Hungary, 1780-1900.” Angol Filológiai Tanulmányok / Hungarian Studies in English vol. 12: 19-36.

Paget, John. 1839. Hungary and Transylvania. London: John Murray.

Paget, John. 1849. Memories VI. Manuscript. Budapest: Széchenyi Library.

Rubies, Joan Pau. 2002. "Travel Writing and Ethnography." In The Cambridge Companion to Travel Writing, eds. Peter Hulme and Tim Youngs, 242-260. Cambridge: Cambridge UP.

Wesselényi, Polixéna. 2006. Olaszhoni és schweizi utazás. 1842. [Travels in Italy and Switzerland.] Ed. Klára Cs. Lingvay. Cluj-Napoca: Kriterion. 